\title{
Measurement of Magnetic-field Distribution Using Pulsed Laser with Magneto-optical Effect
}

\author{
J. Takahashi, S. Hashi, and K. Ishiyama \\ Research Institute of Electrical Communication, Tohoku Univ., Katahira 2-1-1, Aoba-ku, Sendai 980-8577, Japan
}

\begin{abstract}
Electromagnetic interference (EMI) is a serious problem in integrated circuits. The ability to accurately measure low-intensity electromagnetic fields is necessary to overcome this problem. We developed in a previous study a system to make magneto-optical measurements that use short laser pulses and a stroboscopic method to measure magnetic-field waveforms. In this study, we considered the spatial resolution of the system and measured the magnetic field distribution around magnetic heads. The overall results suggest that the system of measurement is capable of measuring EMI if we use a thinner garnet and a higher power laser.
\end{abstract}

Key words: magneto-optical effect, electromagnetic compatibility, magnetic field measurement

\section{パルスレーザを利用した磁気光学効果による磁界分布計測}

\author{
高橋純也・枦修一郎・石山和志
}

東北大学電気通信研究所, 仙台市青葉区片平 2-1-1（テ980-8577）

\section{1. はじめに}

近年，集積回路の高密度化によって伝送線路や電子部品 間の間隔が狭くなっており, さらに低消費電力化を目指し た低電圧駆動により，漏洩電磁波等の EMI (Electromagnetic interference) による影響を受けやすく なるため, 通信の阻害や誤作動を引き起こす問題が䀣念さ れている.この問題を解決するために，集積回路から発生 する漏洩電磁波を低減・防止する必要があり，そのために 微弱な近傍磁界を正確に測定する技術が求められている.

一般的な近傍磁界測定方法としては，シールディドルー プコイルのような金属プローブを用いた方法 1)2)が挙げら れる.しかし，金属製のプローブは本来の磁界分布を乱し てしまう 3). そこで，電磁波の状態を乱さずに測定する方 法として磁気光学効果を用いた低侵襲な測定方法 4)が提案 されているが，交流磁界の位相情報を含んだ測定はできな かった. この問題を解決するため, 筆者らはこれまでに磁 気光学効果とパルスレーザを用いたストロボ法により，1 $\mathrm{MHz}-1 \mathrm{GHz}$ の位相を含んだ磁界波形の測定を行い5), マ イクロストリップ線路から発生する微弱な磁界が測定でき ることを示した 6). しかしながら, 測定磁界の空間分解能 については議論していなかったため, 本報告では本システ ムの空間分解能について検討した. そして, 本システムの 空間分解能を評価するため, 微小な磁界発生源であるハー ドディスクの磁気ヘッド周辺の磁界分布を測定した.

\section{2. 計測方法}

\section{1 測定システム}

Fig. 1 に本研究における磁界測定装置の構成を示す. 磁 界検出には, GGG 基板上に面方位（110）で $(\mathrm{BiLu})_{3}(\mathrm{FeGa})_{5} \mathrm{O}_{12}$ を液層エピタキシー $(\mathrm{LPE})$ 法により成
膜した厚さ $1.07 \mu \mathrm{m}$ の面内方向に異方性を持つ磁性ガーネ ットを使用した。光の減衰量を低減し, 効果的に磁気光学 効果を得るため, 磁性ガーネット上には厚さ約 $500 \mathrm{~nm}$ の $\mathrm{Au}$ の反射膜をコーティングした. 測定対象近傍に磁性ガー ネットを配置してレーザを照射すると，レーザがガーネッ 卜を透過した際に磁気光学効果により偏光状態が変化する. この変化はガーネットに印加されている磁界強度に依存す るため, 偏光状態を観察することで磁界強度の測定が可能 である、レーザは対物レンズを通して集光しており，ガー ネットに対して垂直に入射しているため，ガーネットに対 して垂直方向の磁界成分を測定できる，本報告では，周波 数帯域が DC〜 $100 \mathrm{kHz}$ の差動ディテクタを用い, 差動検 出法により偏光面の回転を検出した。また，使用したレー ザは，外部トリガにより発振するパルス半導体レーザであ り，波長は $670 \mathrm{~nm}, 1 \mathrm{MHz}$ 発振時の平均時間出力は 10.5 $\mu \mathrm{W}$ ，パルス幅は $32 \mathrm{ps}$ である.

本システムでは Fig. 2 に示すようにストロボ法を用いて 磁界測定を行うため，レーザと発生磁界を同期する必要が

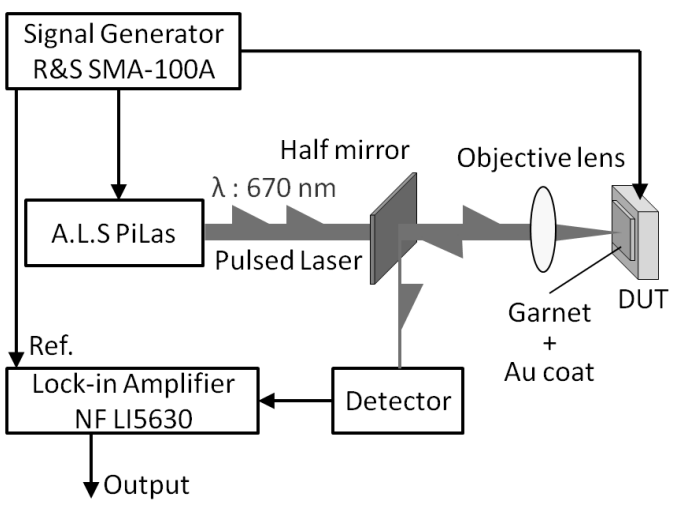

Fig. 1 Schematic structure of measurement system. 
ある、そのため，シグナルジェネレータからはパルスレー ザへのトリガ信号, 磁界を発生させるための測定対象への 印加信号，ロックインアンプヘの参照信号の計 3 つの同期 した信号を出力し, 測定系全体を同期させている.これに より，磁界の周波数がレーザの発振周波数の整数倍の場合 には, 交流磁界の特定位相でのみレーザが発光するため, 任意の位相の磁界強度を測定することができる.また, Fig. 2 (b)のようにレーザと磁界の位相をずらすことで異なる位 相の磁界強度を測定することができる．これを連続的に繰 り返すことで磁界の強度, 周波数, 位相情報の測定が可能 となる。

集積回路から発生する磁界は非常に微弱なため, EMI 測 定技術には高い感度が要求される. しかし, 磁気光学効果 を利用した磁界測定法の場合, 光電変換を行うために感度 が他の測定法と比べて劣ってしまう. フォトディテクタの 周波数応答性と光電变換効率はトレードオフの関係にある ため, 本システムでは周波数応答性は低いものの, 高感度 なフォトディテクタを用い, さらにロックインアンプで検 出することでシステムの高感度化を図っている. 周波数応 答性の低いフォトディテクタの場合, ストロボ法における 光電変換後の出力電圧は Fig. 2 に示すように直流電圧とな る. そのため, 発生磁界もしくはレーザをバースト変調さ せることで出力電圧が交流電圧となり, ロックインアンプ による高感度な測定が可能となる. 本システムでは使用し たフォトディテクタの周波数応答性に合わせて, 発生磁界 を $25 \mathrm{kHz}$ でバースト変調した. それにより, 光電変換後 の出力電圧が $25 \mathrm{kHz}$ で変化する交流信号となる. これら ストロボ法とバースト変調により, 高感度で位相情報を含 んだ磁界測定を可能としている.

\section{2 空間分解能と測定感度について}

一般的な光学顕微鏡やレーザ顕微鏡の場合, 短波長の光 源や高倍率のレンズを用いてスポット径を小さくすること で空間分解能を高めている。しかしながら，本報告では磁 界検出に磁性ガーネットを使用しているため, 本システム の空間分解能はレーザのスポット径に加え, ガーネットの 厚さや異方性にも依存することになる. Fig. 3 はガーネッ トに対物レンズにより集光したレーザが入射している様子 を断面から見た模式図である。ガーネットに磁界が加わっ ている場合, ガーネット内部をレーザが透過したときにフ アラデー効果によりレーザの偏光面が回転する. そのため, Fig. 3 の白い点線で囲んだ範囲のガーネットの磁化状態の 平均值を磁界として検出する. 波長 $670 \mathrm{~nm}$ のレーザを使 用したときのガーネットの厚みとガーネット表面における レーザ直径の関係を Fig. 4 に示す. Fig. 4 より, ガーネッ トの厚みによりガーネット表面に照射するレーザ直径が大 きく変化することがわかる，また，高倍率のレンズの方が スポット径は小さくなるものの, ガーネットの厚みが厚く なってしまうと表面に照射するレーザ直径が低倍率のレン ズよりも大きくなってしまう。ガーネットが厚い場合, 全 体的な透過範囲を考えると低倍率のレンズのほうが高い空 (a)

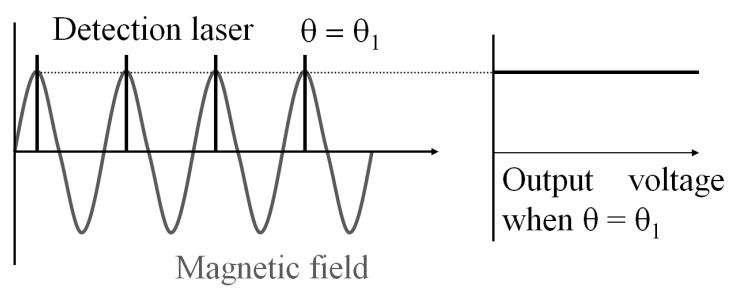

(b)

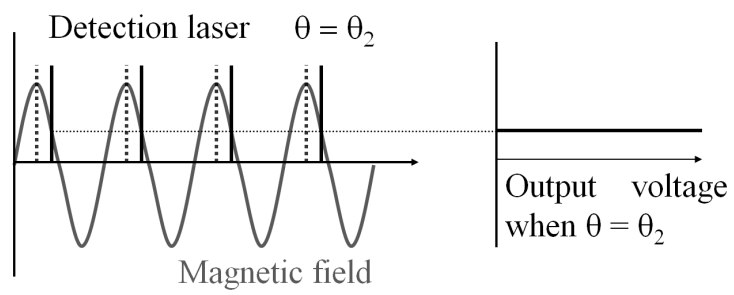

Fig. 2 Stroboscopic method (left) and photodiode output (right).

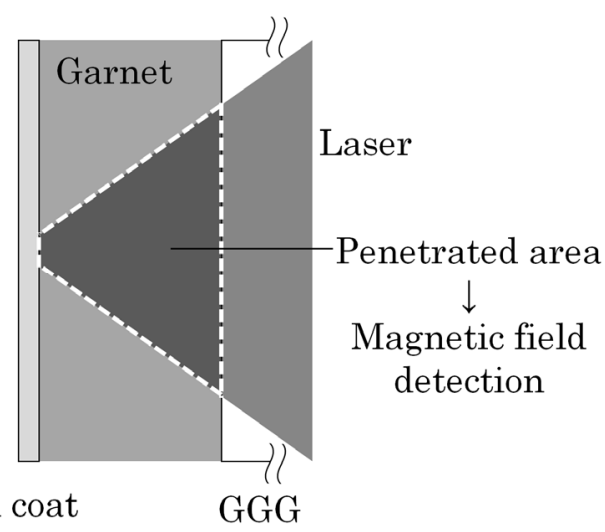

Fig. 3 Schematic of laser beam and garnet.

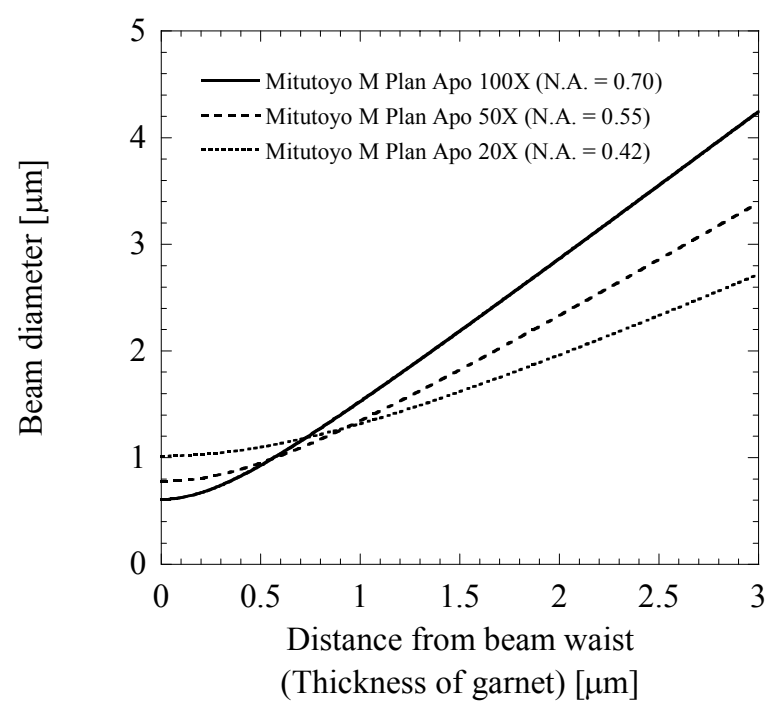

Fig. 4 Relationship between thickness of garnet and laser beam diameter.

間分解能が得られると考えられるため, 厚さに適した倍率 のレンズを選定する必要がある。それに対して, ガーネッ トが薄い場合, スポット径同等の空間分解能が得られると 考えられるため, 高い空間分解能を得るためには薄いガー ネットを使用すればよい.また，ガーネットの異方性に関 
しては，垂直方向の磁界を検出する際に垂直磁気異方性を 有したガーネットを使用した場合, 磁壁移動による磁化反 転となるため, 磁壁の大きさ（約 $5 \mu \mathrm{m} ）$ により空間分解能 が制限されてしまう. そのため, 高空間分解能化のために は面内異方性を有するガーネットを使用することが望まし い.

以上，本システムの空間分解能について述べた．次に測 定感度について述べる. 本システムの測定感度は主にフォ トディテクタの感度とレーザパワー, 磁気光学効果の大き さにより決定される. (1)フォトディテクタが高感度になる ことで弱いレーザでも大きな出力を得ることができ, (2)レ 一ザパワーが大きくなることで, 強いレーザをフォトディ テクタに入射することができるため, それぞれ光電変換後 の出力を上げることができる. また, (3)磁気光学効果が大 きくなることで, より光の偏光面が回転して差動検出によ る出力が大きくなるため, これら三つの要素を考慮するこ とでシステム全体の感度を向上させることができる，本報 告では, 高感度なフォトディテクタを使用し, バースト変 調によるロックインアンプでの測定を行っているため, さ らなる感度向上のためにはレーザパワーと磁気光学効果を 大きくする必要がある.レーザパワーに関しては, 繰り返 し周波数の高いパルスレーザや高出力のパルスレーザを用 いればよい. 例えば, $100 \mathrm{MHz}$ で発振するパルスレーザを 使用した場合, 平均時間出力は約 $500 \mu \mathrm{W}$ となり, 本報告 で使用しているレーザパワーの約 50 倍に相当するため, 感 度も同等程度向上すると考えられる. また, 磁気光学効果 に関しては, 磁気光学材料の組成や厚みにより磁気光学効 果の大きさが変化する. Bi 置換ガーネットの場合, Bi の置 換量を多くすることで磁気光学効果が増大し 7 , , 厚みを厚 くすることでファラデー効果による磁気光学効果を大きく することができる，ただし，厚いほど光の透過率が悪くな り, フォトディテクタに入射するレーザ光が弱くなってし まうため, ガーネットを厚くすればするほど感度が向上す るとは限らない.

以上述べてきた空間分解能と測定感度の関係を Table 1 に示す. Table 1 より, 空間分解能と測定感度は互いに相 反する特性があり，両立させることは難しい，例えば，ガ 一ネットの厚さに関しては高感度化のためには厚く, 高空 間分解能化のためには薄くすることが望ましい. そこで本 報告ではこれらの関係を考慮し, 比較的厚みの薄い 1.07 $\mu \mathrm{m}$ 厚の面内異方性を有したガーネットと 50 倍の対物レン

Table 1 Relationship between spatial resolution and sensitivity.

\begin{tabular}{|c|c|}
\hline \hline High spatial resolution & High sensitivity \\
\hline In-plane magnetic anisotropy & High sensitivity photodetector \\
Short wavelength laser & High power laser \\
High power objective lens & Thick garnet \\
Thin garnet $\stackrel{\text { Trade-off }}{\longrightarrow}$ 年 \\
\hline
\end{tabular}

ズ (Mitutoyo M Plan Apo 50X) を使用した。この構成の 場合, Fig. 4 からわかるようにレーザのスポット径は 0.78 $\mu \mathrm{m}$, ガーネット表面におけるレーザ径は $1.4 \mu \mathrm{m}$ となるた め, 空間分解能は $1 \mu \mathrm{m}$ 程度になると予想される. そして, 空間分解能を評価するための微小な磁界発生源として, 面 内磁気記録方式である Western Digital の WD800BB の磁 気ヘッドを測定対象とし, 磁気ヘッドから発生する磁界分 布を測定した. このハードディスクのトラック幅は 0.466 $\mu \mathrm{m}$, 磁気へッドの書き込み磁極幅は SEM で観察したとこ ろ, $0.5 \mu \mathrm{m}$ 程度であった。

\section{3. 計測結果 · 考察}

\section{1 磁性ガーネットの直流磁場特性}

ストロボ法では, 測定した磁界の強さを電圧として出力 するため, 出力電圧から磁界強度を算出する必要がある. 使用したガーネットは $2 \mathrm{GHz}$ 付近で強磁性共鳴が確認で きたため, それより低い周波数ならば透磁率はほぼ一定と 考えられる。したがって, 磁性ガーネットに直流磁場を印 加して磁界強度に対する出力電圧特性を測定することで, $2 \mathrm{GHz}$ 以下の周波数において磁界強度の算出を行うことが できる.外部トリガ信号として, $1 \mathrm{MHz}$ の矩形波を $25 \mathrm{kHz}$ でバースト変調した信号をパルスレーザへ入力し, ガーネ ットに直流磁場を印加して出力特性を測定した. Fig. 5 に 直流磁場に対するガーネットの出力特性を示す。この傾き を求めると, $1 \mathrm{Oe}$ 当たりの出力電圧は $6.03 \mu \mathrm{V} / \mathrm{Oe}$ となっ た。以降, この測定結果から得られた值を元に出力電圧か ら磁界強度を算出した。

\section{2 磁気ヘッドの磁界波形計測}

磁気ヘッドにガーネットを近接させ, 磁気ヘッドから発 生する磁界を測定した。このとき, 磁気へッドとガーネッ ト間には $\mathrm{Au}$ の反射膜が $500 \mathrm{~nm}$ あるため, 磁気へッドか ら500 nm 程度離れた位置の発生磁界を測定したことにな る. パルスレーザを $1 \mathrm{MHz}$ で発振し, 磁気ヘッドに 100 $\mathrm{MHz}$ の正弦波信号を $25 \mathrm{kHz}$ でバース卜変調し, $5.7 \mathrm{mAp}-\mathrm{p}$ の電流を流した。本来の磁気ヘッドに流す電流值よりも小 さいが, ガーネットが $600 \mathrm{Oe}$ 程度で飽和してしまうため, ここでは比較的小さい電流を流した. Fig. 6 に磁気へッド の書き込み磁極部分の磁界波形測定結果を示す.レーザと 磁界の位相を 0.2 deg.ずつずらしながら, 各位相における 磁界強度の 1000 回分のデータを平均化してプロットした. $360^{\circ}$ で一周期分の正弦波が確認でき, 発生磁界と対応した 磁界波形が得られていることがわかる.

\section{3 磁気ヘッドの周辺磁界分布計測}

磁界波形計測では，レーザを入射している一点の磁界を 位相をずらしながら測定したが, 磁界分布計測では特定位 相のままレーザの入射点を走査することで磁界分布測定を 行う。レーザの走查には, 測定対象側に XY 自動ステージ （駿河精機 PMG-650）を用い，20×20 $\mu \mathrm{m}$ の範囲を XY 軸各方向に $0.2 \mu \mathrm{m}$ ずつ走査して各位置における磁界強度 を測定した。 1 点の測定に対して，ステージの移動時間及 
び待機時間を合わせて $0.3 \mathrm{~ms}$ に設定し，1つの磁界分布測 定に約 15 分かけて測定を行った.

Fig. 7 に位相が-90 deg., 0 deg., 90 deg. における磁 気へッドから発生する磁界分布計測結果を示す。+と一お よび白から黒のコントラストはガーネットの面直方向の磁 界, つまり磁気ヘッドから発生する垂直方向の磁界の強さ を表している. - $90 \mathrm{deg}$.と $90 \mathrm{deg}$.の位相において, 記録 媒体へ書き込む際の強力な磁界が発生しており, ギャップ を介して書き込み磁界とは反対方向の微弱な磁界が平面的 に発生している様子がわかる０ｏｄeg.の位相においては， 磁界波形測定結果と同様に磁気へッドから発生する磁界は ほとんど検出されなかった。磁界の計測結果が $90 \mathrm{Oe}$ と磁 気へッドから発生する磁界にしては小さいが，これは電流 值が小さいことに加え, 磁性ガーネットと磁気ヘッド間の 距離が $500 \mathrm{~nm}$ 程度離れているためだと考えられる.

\section{4 空間分解能の評価}

測定対象であるハードディスクのトラック幅が 0.466 $\mu \mathrm{m}$, 磁気へッドの書き込み磁極幅が約 $0.5 \mu \mathrm{m}$ であり, レ ーザのスポット径よりも小さいため, ここでは磁極部分の 磁界分布の半值幅を空間分解能として定義した. 空間分解 能が十分に高ければ, $0.5 \mu \mathrm{m}$ 幅の急峻な磁界が測定される

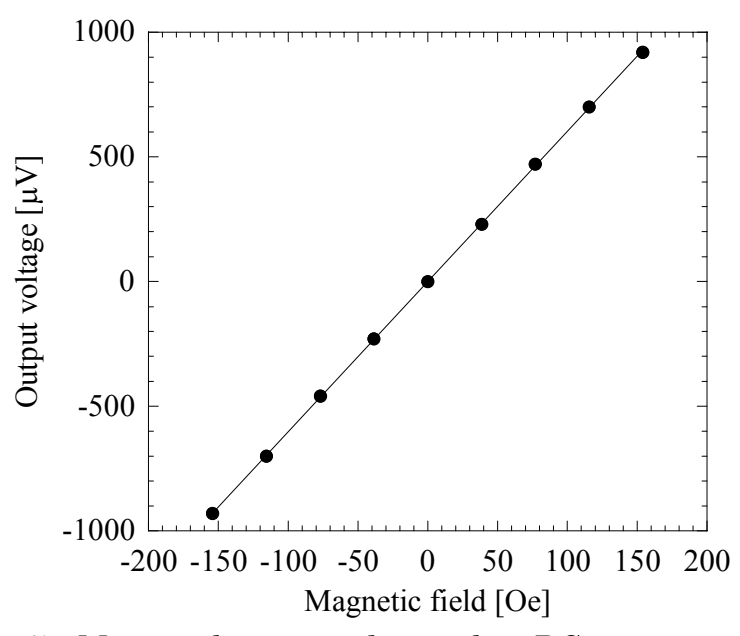

Fig. 5 Measured output voltage when DC magnetic field was applied.

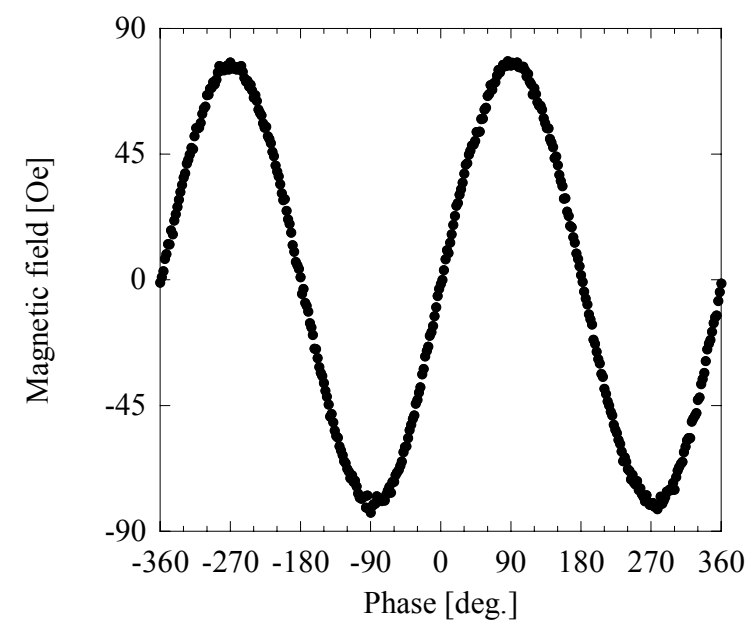

Fig. 6 Measured magnetic field waveform.

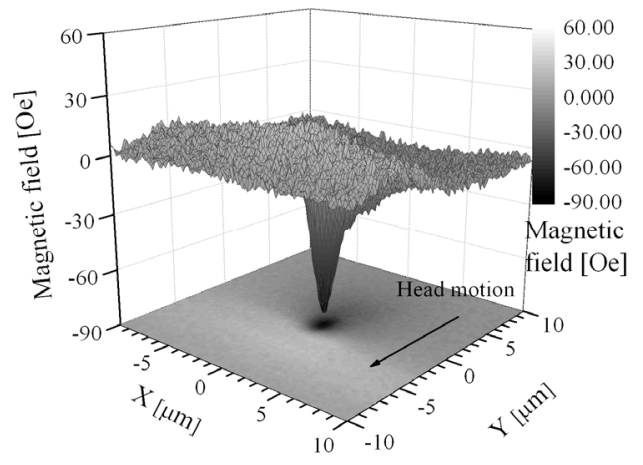

(a) $-90 \mathrm{deg}$.

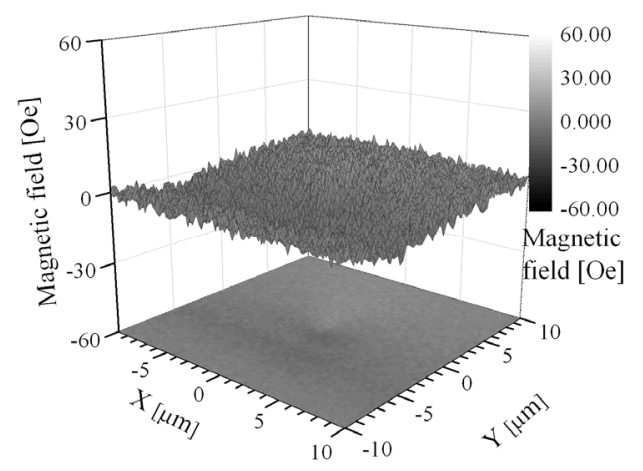

(b) 0 deg.

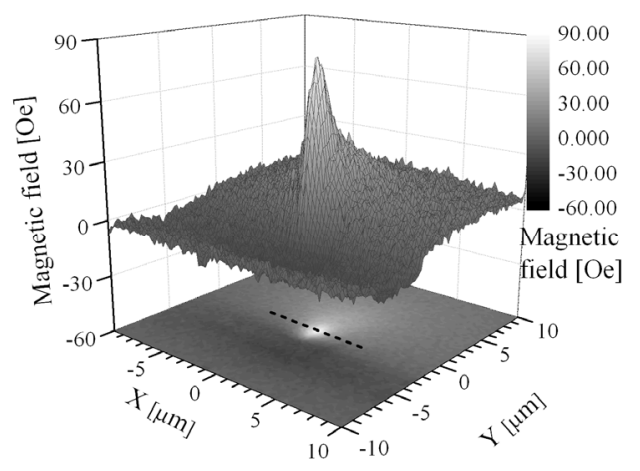

(c) $90 \mathrm{deg}$.

Fig. 7 Measured magnetic field distribution around magnetic head.

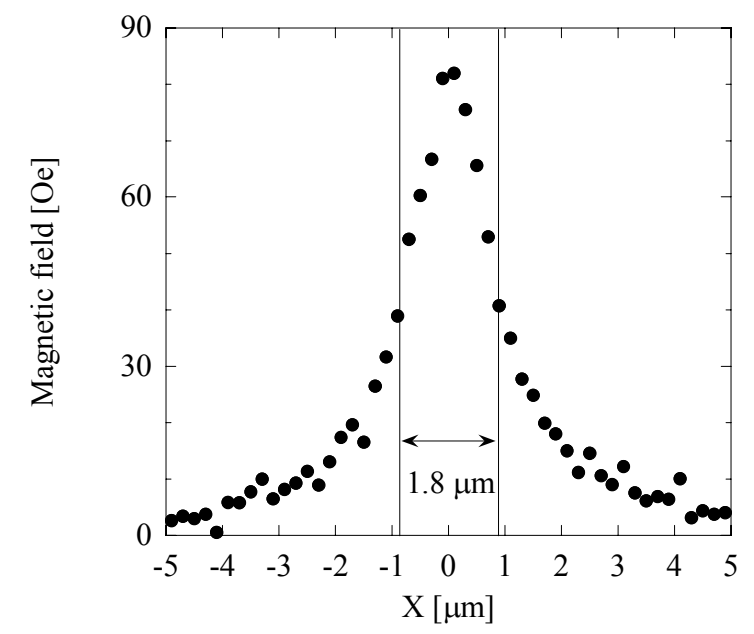

Fig. 8 Field strength on dotted line in Fig. 7(c). 
はずである. Fig. 8 に書き込み磁極部分である Fig. 7(c)の 点線部分における磁界強度を示す. Fig. 8 より, 半值幅か ら空間分解能を求めると $1.8 \mu \mathrm{m}$ であり, 予想したよりも 低い空間分解能となった。 本報告では, ガーネットと磁気 ヘッド間の距離が $500 \mathrm{~nm}$ 程度離れているため, 磁気へッ ドが記録媒体へ書き込む際の磁界よりも空間的に広がった 磁界を測定したためだと考えられる. 薄いガーネットに加 え, 反射膜を薄くすることで, 試料とガーネット間の距離 を近接させることができるため, さらに空間分解能が向上 すると考えられる。

\section{4. まとめ}

磁気光学効果とストロボ法を用いた本システムの空間分 解能について評価・検討を行った. 高い空間分解能を得る ために，面内異方性を持ったガーネットを用い，ガーネッ トの厚さとスポット径, 焦点位置を考慮した. そして, 空 間分解能を評価するために磁気へッド周辺の磁界分布を測 定した. 磁気ヘッド書き込み磁極部分の磁界分布結果から 本システムの空間分解能を見積もったところ, $1.8 \mu \mathrm{m}$ であ った.

本報告では, 磁気へッドという強力な磁界発生源からの 磁界を測定したが, 本来は EMI 測定を目的とした測定法で ある。そのため, EMI 測定に適用するためにもさらに空間 分解能と感度を高める必要がある. 現時点で有効的に空間 分解能と感度を高めるには, 高出力のレーザとさらに薄い ガーネットや反射膜を用いればよい. 本報告で使用したレ ーザは平均時間出力 $10.5 \mu \mathrm{W}$ という低出力のレーザを用い ているため, 高出力のレーザを用いることで感度は大幅に 改善すると考えられる. そして, 薄いガーネットを用いる
ことで感度は低下するものの, 高出力レーザによる感度の 増加分を考えると, 本報告よりも空間分解能と感度が向上 し，EMI 測定への適用も可能ではないかと考えられる。

謝辞 磁性ガーネット薄膜を御提供頂きました名古屋工業 大学先進セラミックス研究センター安達信泰准教授に感謝 致します。

\section{References}

1) J.D. Dyson: "Measurement of near fields of antennas and scatterers", IEEE Trans. Antennas and Propagation, vol. AP-21, pp. 446-460 (1973).

2) N. Tamaki et al: "A Miniature Thin-Film Shielded-Loop Probe with a Flip-Chip Bonding for Magnetic Near field Measurements", IEICE Trans. Electron., Vol. J87-C, No. 3, pp. 335-342 (2004).

3) M. Takahashi, H. Ota, K. I. Arai and R. Sato: "Magnetic Near-Field Distribution Measurements above a Patch Antenna by Using an Optical Waveguide Probe", IEICE Trans. Commun., E88-B, pp. 3140-3145 (2005).

4) M. Takahashi, K. Kawasaki, H. Ohba, T. Ikenaga, H. Ota, T. Orikasa, N. Adachi, K. Ishiyama, and K. I. Arai: "Electromagnetic near field measurements by using magnet garnet crystal", J. Appl. Phys., vol. 107, 09E711 (2010).

5) H. Nasuno, S. Hashi, K. Ishiyama: "Stroboscopic technique for measuring magnetic-field waveforms utilizing magneto-optical effect", IEEE Trans. Magn., vol. 47, pp. 4011-4013 (2011).

6) J. Takahashi, H. Nasuno, S. Hashi, K. Ishiyama: "Magnetic field waveform measurement of microstrip line using pulsed laser", DIGESTS OF THE 35TH ANNUAL CONFERENCE ON MAGNETICS IN JAPAN, p58 (2011).

7) T. Kosaka, M. Naganuma, M. Aoyagi, T. Kobayashi, S. Niratisairak, T. Nomura, T. Ishibashi: "Preparation and Characterization of $\mathrm{Y}_{3} \times \mathrm{BixFe}_{5} \mathrm{O}_{12}$ Films for Magneto-optical Indicator Films By Metal Organic Decomposition”, J. Magn. Soc. Jpn., vol. 35, pp. 194-198 (2011).

2012年10月19日受理，2012年12月18日再受理，2013年1月15日採録 